\section{Potential of Producing Salicornia bigelovii Hydroponically as a Vegetable at Moderate NaCl Salinity}

\author{
Yun Kong and Youbin Zheng ${ }^{1}$ \\ School of Environmental Sciences, University of Guelph, Guelph, ON N1G \\ 2W1, Canada; and Vineland Research and Innovation Centre, Vineland, \\ Ontario, Canada
}

Additional index words. biomass accumulation, $\mathrm{NaCl}$ concentration, plant growth, sodium uptake, water consumption

\begin{abstract}
Salicornia bigelovii is a halophyte that is capable of growing under high salinity. To evaluate the potential of producing $S$. bigelovii hydroponically as a vegetable at moderate $\mathrm{NaCl}$ concentrations, plants were grown in nutrient solutions with 6,8 , and $10 \mathrm{~mm} \mathrm{NaCl}$, and with $200 \mathrm{~mm} \mathrm{NaCl}$ as a control. Results showed that plants had a reduced main stem length, canopy width, stem diameter, and root system length in 6 to $10 \mathrm{~mm} \mathrm{NaCl}$ compared with those in $200 \mathrm{~mm}$. Also, fresh weight increase, fresh and dry weights of individual plants, marketable yield, and water use efficiency of the plants grown in solutions with 6 to $10 \mathrm{~mm} \mathrm{NaCl}$ were significantly lower than those grown in $200 \mathrm{~mm}$. Associated with the reduced growth attributes, remarkable decreases in sodium uptake by the plants were also obtained in 6 to $10 \mathrm{vs.} 200 \mathrm{~mm} \mathrm{NaCl}$. The results suggest that $S$. bigelovii is not a good candidate for hydroponic production as a vegetable at moderate $\mathrm{NaCl}$ salinity resulting from reduced growth attributes, which are possibly associated with decreased sodium uptake.
\end{abstract}

Hydroponic vegetable growers are searching for ways of reducing discharge and increasing on-farm reuse of drainage (Shannon and Grieve, 2000), because discharge wastes both water and fertilizer, pollutes the environment, and sometimes even results in soil salinization (Varlagas et al., 2010). One of the most important factors limiting the reuse of nutrient solutions for hydroponic production of common vegetables (e.g., cucumber, tomato, and pepper) is elevated salinity (Van Os, 1998), resulting mainly from $\mathrm{Na}^{+}$and $\mathrm{Cl}^{-}$ accumulations attributable to differential ion uptake by these crops (Kronzucker and Britto, 2011; Savvas et al., 2005). An alternative strategy is to reuse these salinized solutions for hydroponic production of another economically valuable and more salt-tolerant crop (Grieve and Suarez, 1997; Kong and Zheng, 2014; Pardossi et al., 1999). It requires that this species has the ability to withstand elevated salinity levels without growth inhibition and reduced productivity while providing a saleable product (Adler et al., 2003; Grieve and Suarez, 1997).

Salicornia bigelovii has been listed as one of the most salt-tolerant species among 1560 halophytes and has been shown to maintain

\footnotetext{
Received for publication 29 Apr. 2014. Accepted for publication 3 July 2014.

We thank Mary Jane Clark, Eric Rozema, and Katherine Vinson for their technical support. Thanks also to the anonymous reviewers for their very useful suggestions on the revision of this manuscript.

${ }^{1}$ To whom reprint requests should be addressed; e-mail yzheng@uoguelph.ca.
}

normal growth even when soil $\mathrm{NaCl}$ concentration exceeds $1.3 \mathrm{M}$, two times greater than full-strength seawater salinity $(\approx 500 \mathrm{~mm}$ $\mathrm{NaCl}$; Glenn et al., 1999). Also, S. bigelovii has been introduced to U.S. and European fresh produce markets as a specialty vegetable where its succulent young shoots are sold as 'Samphire' or 'Sea asparagus' and are in high demand in gourmet kitchens not only for their salty taste, but also for their high nutritional value (Ventura et al., 2011; Ventura and Sagi, 2013). S. bigelovii has been evaluated and cultivated commercially as a vegetable in Mexico, the Middle East, and Africa (Jaradat and Shahid, 2012; Ventura and Sagi, 2013; Zerai et al., 2010).

Can S. bigelovii be used for hydroponic production as a vegetable in the salinized discharged solutions mentioned before? Currently, limited information is available to answer this question. Grattan et al. (2008) has found that $S$. bigelovii has the potential to reuse hypersaline drainage water and that it is able to grow well at one-third strength to full-strength seawater salinity. In the previously mentioned study, the plants were evaluated under relatively high $\mathrm{NaCl}$ concentrations, i.e., $\approx 150$ to $500 \mathrm{~mm}$ (Grattan et al., 2008). However, the $\mathrm{NaCl}$ concentration of most nutrient solutions discharged from hydroponic production of common vegetables ranges from 6 to $8 \mathrm{~mm}$, a moderate $\mathrm{NaCl}$ salinity (Van Os, 1998). Some studies indicate that $S$. bigelovii inhabits the broadest range of salinity and has very little phenotypic response to salinity gradient (Dagar, 2005; Jaradat and Shahid, 2012). Also, the plants of this species have not shown significant differences in the growth rate and biomass accumulation at a salinity between 0.5 and 10 ppt $(\approx 9$ and $\approx 180 \mathrm{~mm} \mathrm{NaCl}$, respectively) until 35 ppt $(\approx 630 \mathrm{~mm} \mathrm{NaCl}$; Brown et al., 1999). Conversely, other studies suggest the optimal $\mathrm{NaCl}$ concentration for S. bigelovii growth ranges from 170 to $200 \mathrm{~mm}$ (Ayala and O'Leary, 1995; Webb, 1966) or 100 to $400 \mathrm{~mm}$ (Parks et al., 2002), and a suboptimal $\mathrm{NaCl}$ concentration of $5 \mathrm{~mm}$ can cause decreased plant growth associated with reduced sodium uptake (Ayala and O'Leary, 1995). Because the reported results differ, further research is needed to determine whether there will be significant reductions in plant growth and sodium uptake for $S$. bigelovii grown hydroponically at moderate $\mathrm{NaCl}$ concentrations (i.e., 6 to $10 \mathrm{~mm}$ ).

The overall objective of this study was to evaluate the potential of producing $S$. bigelovii hydroponically as a vegetable at moderate $\mathrm{NaCl}$ concentrations, the salinity level of nutrient solution discharged from hydroponic production of common vegetables.

\section{Materials and Methods}

Plant materials and growing conditions. The study was conducted in a greenhouse in the Edmund C. Bovey building at the University of Guelph, Guelph, Ontario, Canada (lat. $43^{\circ} 33^{\prime} \mathrm{N}$, long. $80^{\circ} 15^{\prime} \mathrm{W}$ ). Seeds of $S$. bigelovii (Serra Maris Company, Ninove, Belgium) were sown in a medium with a peat-perlite ratio of $1: 1$ by volume on 21 June 2013. One month after sowing, seedlings with a height of $\approx 3 \mathrm{~cm}$ were transplanted into rockwool cubes (1.5" Starter Plugs; Grodan Inc., Ontario, Canada), which were embedded in a Styrofoam disk floating on the nutrient solution in a plastic pot (14-cm top and 12-cm bottom diameters $x$ $15 \mathrm{~cm}$ high). Each pot had one Styrofoam disk with four seedlings growing in individual rockwool cubes, except for the control pot, which had only a Styrofoam disk and four unplanted rockwool cubes. Each pot contained $\approx 1.5 \mathrm{~L}$ of solution with the following nutrients $\left(\mathrm{mg} \cdot \mathrm{L}^{-1}\right): 278.3$ nitrogen, 36.7 phosphorus, 420 potassium, $97.6 \mathrm{cal}-$ cium, 1.58 magnesium, 100.8 sulfur, 0.53 copper, 0.21 boron, 0.53 manganese, 0.53 zinc, 0.16 molybdenum, and 1.05 iron. Five days after transplanting, the nutrient solutions were changed for all the pots, and $\mathrm{NaCl}$ was added to the solutions to achieve four treatment concentrations: $6,8,10$, and 200 (control) $\mathrm{mm}$, which indicated the start of treatment. The initial $\mathrm{Na}^{+}$concentrations of the four salt-treated nutrient solutions were measured as $6.8 \pm 0.1,8.7 \pm 0.0,10.6 \pm 0.1$, and $213.9 \pm 3.3 \mathrm{~mm}$, respectively, with the electrical conductivity of $3.38 \pm 0.03,3.52 \pm$ $0.05,3.75 \pm 0.04$, and $21.65 \pm 0.70 \mathrm{dS} \cdot \mathrm{m}^{-1}$, respectively. The nutrient solutions were changed every $7 \mathrm{~d}$ to reduce nutrient and $\mathrm{NaCl}$ concentration variability during the experiment and to maintain a nutrient solution $\mathrm{pH}$ range of 5.5 to 7.0. Pots were arranged in a randomized block design with four blocks and four $\mathrm{NaCl}$ concentrations within each block. 
The greenhouse conditions were set at 18-h light/6-h dark by supplementing natural sunlight with high-pressure sodium lamps to achieve a photosynthetically active radiation at the canopy level averaging no less than $397 \pm 34 \mu \mathrm{mol} \cdot \mathrm{m}^{-2} \cdot \mathrm{s}^{-1}$ and 22 to $28{ }^{\circ} \mathrm{C}$ light $/ 20$ to $22{ }^{\circ} \mathrm{C}$ dark with a relative humidity between $50 \%$ and $60 \%$.

Measurements of plant growth and sodium uptake. Two plants were randomly chosen from each pot within each block for growth measurements. Every week the following attributes were measured: main stem length, node number and side branch number on the main stem, and canopy width. Four weeks after the start of treatment, seedlings were taken out of the solutions for photographing. The lengths of root systems and diameters of main stems and side branches were measured at the final harvest.

The fresh weight (FW) increase rate was determined weekly after the start of treatment until harvest. At harvest ( $28 \mathrm{~d}$ after the start of treatment), FW and dry weight (DW) of individual plants, marketable yield, and water use efficiency were estimated following the methods described by Kong and Zheng (2014).

Also at harvest, the total $\mathrm{Na}^{+}$removal amount (mmol/plant), water consumption (L/plant), $\mathrm{Na}^{+}$removal efficiency $\left(\mathrm{mol} \cdot \mathrm{kg}^{-1}\right.$ DW), and $\mathrm{Na}^{+}$uptake concentration ( $\mathrm{mmol} \cdot \mathrm{L}^{-1}$ $\mathrm{H}_{2} \mathrm{O}$ ) were evaluated following the same methods used by Kong and Zheng (2014).

Statistical analysis. Data were subjected to analysis of variance using DPS (Data Processing System) Software (Version 7.05; Refine Information Tech. Co., Hangzhou, China) and were presented as mean \pm SE; separation of means was performed using Duncan's new multiple range test at the $P \leq$ 0.05 level. Correlation analysis was used to determine the relationship between the parameters of $\mathrm{Na}^{+}$uptake and biomass accumulation.

\section{Results}

Plant growth. The plants grown in 6 to $10 \mathrm{~mm} \mathrm{NaCl}$ had a smaller main stem length and canopy width 14 to $28 \mathrm{~d}$ after the start of treatment (Fig. 1A-B) when compared with those in $200 \mathrm{~mm} \mathrm{NaCl}$. However, throughout the experiment, the number of nodes and side branches on the main stem did not significantly differ among the four $\mathrm{NaCl}$ treatments (data not shown). At the time of harvest, plants grown in 6 to $10 \mathrm{~mm} \mathrm{NaCl}$ appeared less succulent and had smaller plant canopies, shorter root systems, and thinner main stems and side branches compared with those in $200 \mathrm{~mm} \mathrm{NaCl}$ (Table 1).

The FW increase rate was similar during the first week of treatment, but it was lower for plants in the 6 to 10 vs. $200 \mathrm{~mm} \mathrm{NaCl}$ treatments during 7 to $28 \mathrm{~d}$ after the start of treatment (Fig. 2). Moreover, the difference in the FW increase rate between the 6 to 10 and $200 \mathrm{~mm} \mathrm{NaCl}$ treatments increased over time (Fig. 2). At harvest, the FW and DW of individual plants, marketable yield, and water use efficiency of the plants grown in 6
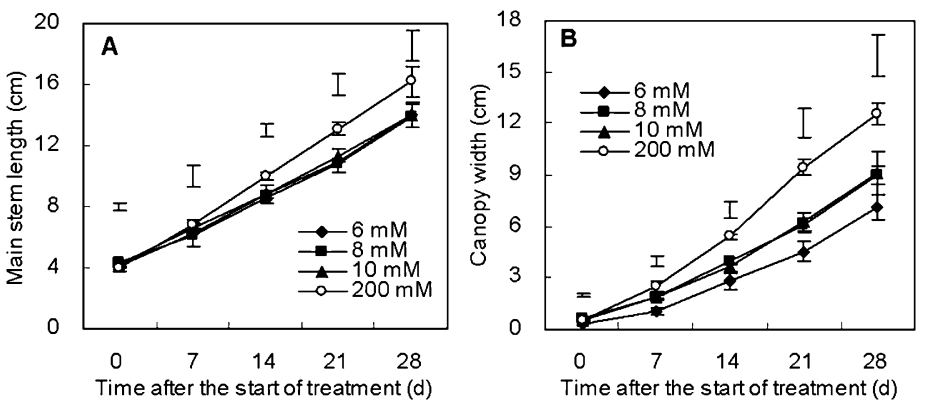

Fig. 1. The temporal variation of main stem length (A) and canopy width $(\mathbf{B})$ of Salicornia bigelovii grown in hydroponic solutions with different $\mathrm{NaCl}$ concentrations. Data are means $\pm \mathrm{SE}(\mathrm{n}=8)$. Where bars are not visible, SE does not exceed the size of the symbol. The bars above the lines indicate least significant difference ${ }_{0.05}$ for each measuring day.

Table 1. Root system length, main stem diameter, and side branch diameter at final harvest for Salicornia bigelovii grown in hydroponic solutions with different $\mathrm{NaCl}$ concentrations.

\begin{tabular}{llcc}
\hline $\begin{array}{l}\text { Added } \mathrm{NaCl} \\
\text { concn }(\mathrm{mM})\end{array}$ & $\begin{array}{l}\text { Root system } \\
\text { length }(\mathrm{cm})\end{array}$ & $\begin{array}{c}\text { Main stem } \\
\text { diam }(\mathrm{mm})\end{array}$ & $\begin{array}{c}\text { Side branch } \\
\text { diam }(\mathrm{mm})\end{array}$ \\
\hline 6 & $11.0 \pm 0.6^{\mathrm{z}} \mathrm{b}^{\mathrm{y}}$ & $2.23 \pm 0.12 \mathrm{c}$ & $1.49 \pm 0.17 \mathrm{~b}$ \\
8 & $11.3 \pm 0.7 \mathrm{~b}$ & $2.22 \pm 0.13 \mathrm{c}$ & $1.65 \pm 0.14 \mathrm{~b}$ \\
10 & $13.2 \pm 1.3 \mathrm{~b}$ & $2.55 \pm 0.10 \mathrm{~b}$ & $1.81 \pm 0.10 \mathrm{~b}$ \\
200 & $24.2 \pm 2.5 \mathrm{a}$ & $2.92 \pm 0.08 \mathrm{a}$ & $2.31 \pm 0.06 \mathrm{a}$ \\
\hline
\end{tabular}

${ }^{\mathrm{z}}$ Data are means $\pm \mathrm{SE}(\mathrm{n}=8)$.

${ }^{y}$ Different letters within a column denote significant differences $(P \leq 0.05)$ according to Duncan's new multiple range test.

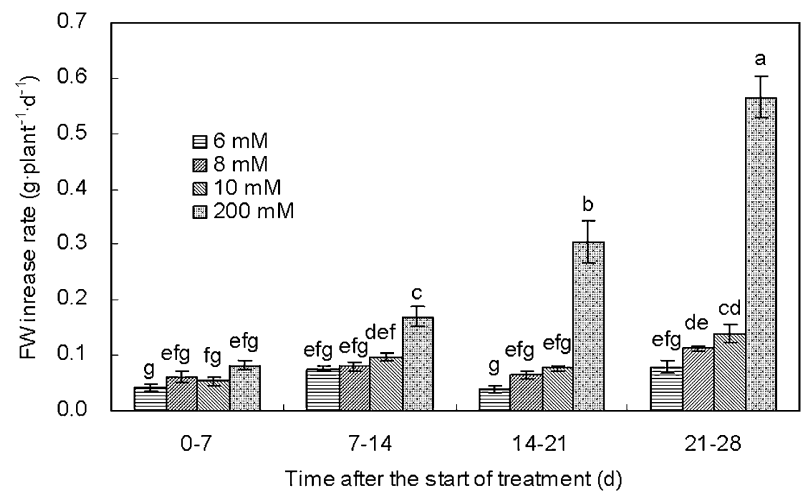

Fig. 2. Fresh weight (FW) increase rate at different times after the start of treatment for Salicornia bigelovii grown in hydroponic solutions with different $\mathrm{NaCl}$ concentrations. Data are means $\pm \mathrm{SE}(\mathrm{n}=4)$. Bars bearing the same letter are not significantly different at $P \leq 0.05$ according to Duncan's new multiple range test.

to $10 \mathrm{~mm} \mathrm{NaCl}$ were 3 -fold lower than those in $200 \mathrm{~mm} \mathrm{NaCl}$ (Table 2).

Sodium uptake. At final harvest, significant decreases were observed in sodium uptake and water consumption by plants when solution concentrations of $\mathrm{NaCl}$ decreased from 200 to 6 to $10 \mathrm{~mm}$ (Table 3 ). Plants exposed to 6 to 10 vs. $200 \mathrm{~mm} \mathrm{NaCl}$ showed $\approx$ a 40-, 15-, and 30-fold decrease in $\mathrm{Na}^{+}$removal amount, $\mathrm{Na}^{+}$removal efficiency, and $\mathrm{Na}^{+}$uptake concentration, respectively, but less than a 2 -fold reduction in water consumption.

\section{Discussion}

Moderate $\mathrm{NaCl}$ salinity inhibits plant growth of hydroponic S. bigelovii. High growth rate is one of the advantages of hydroponic production over soil cultivation for leafy vegetables (Kaşkar et al., 2008). However, in the present study, S. bigelovii reduced plant growth (i.e., main stem length, canopy width, stem diameter, and root length) in 6 to 10 vs. $200 \mathrm{~mm} \mathrm{NaCl}$. This reduction would lead to a longer production period for $S$. bigelovii when grown under moderate vs. high $\mathrm{NaCl}$ concentrations.

Similar to our results, Ayala and O'Leary (1995) reported that hydroponic $S$. bigelovii showed a lower plant height in 5 vs. $200 \mathrm{~mm}$ $\mathrm{NaCl}$ and they attributed the reduced plant growth to toxic effects after hyperaccumulation of $\mathrm{K}^{+}, \mathrm{Ca}^{2+}$, and $\mathrm{Mg}^{2+}$ by shoots to compensate for sodium deficiency. Also consistent with our results, their study indicated that plants grown at suboptimal salinity were less succulent and had significantly smaller stem diameters, possibly because of a reduction in cell size (Ayala and O'Leary, 1995). 
Table 2. Fresh and dry weights, marketable yield, and water use efficiency $28 \mathrm{~d}$ after the start of treatment for Salicornia bigelovii grown in hydroponic solutions with different $\mathrm{NaCl}$ concentrations.

\begin{tabular}{lcccc}
\hline $\begin{array}{l}\text { Added } \mathrm{NaCl} \\
\text { concn }(\mathrm{mm})\end{array}$ & Fresh wt (g/plant) & Dry wt $(\mathrm{g} /$ plant $)$ & $\begin{array}{c}\text { Marketable yield } \\
\left(\mathrm{kg} \cdot \mathrm{m}^{-2}\right)\end{array}$ & $\begin{array}{c}\text { Water use efficiency } \\
\left(\mathrm{g} \text { fresh weight } / \mathrm{L} \mathrm{H}_{2} \mathrm{O}\right)\end{array}$ \\
\hline 6 & $1.63 \pm 0.16^{\mathrm{z}} \mathrm{b}^{\mathrm{y}}$ & $0.21 \pm 0.02 \mathrm{~b}$ & $0.33 \pm 0.03 \mathrm{~b}$ & $5.39 \pm 0.40 \mathrm{~b}$ \\
8 & $2.22 \pm 0.10 \mathrm{~b}$ & $0.26 \pm 0.01 \mathrm{~b}$ & $0.45 \pm 0.02 \mathrm{~b}$ & $7.13 \pm 0.38 \mathrm{~b}$ \\
10 & $2.61 \pm 0.39 \mathrm{~b}$ & $0.28 \pm 0.03 \mathrm{~b}$ & $0.53 \pm 0.08 \mathrm{~b}$ & $7.81 \pm 1.07 \mathrm{~b}$ \\
200 & $7.91 \pm 0.93 \mathrm{a}$ & $0.71 \pm 0.07 \mathrm{a}$ & $1.69 \pm 0.21 \mathrm{a}$ & $20.98 \pm 1.77 \mathrm{a}$ \\
\hline
\end{tabular}

${ }^{\mathrm{z}}$ Data are means \pm SE $(\mathrm{n}=4)$.

${ }^{y}$ Different letters within a column denote significant differences $(P \leq 0.05)$ according to Duncan's new multiple range test.

Table 3. $\mathrm{Na}^{+}$removal amount, $\mathrm{Na}^{+}$removal efficiency, $\mathrm{Na}^{+}$uptake concentration, and water consumption $28 \mathrm{~d}$ after the start of treatment for Salicornia bigelovii grown in hydroponic solutions with different $\mathrm{NaCl}$ concentrations.

\begin{tabular}{lcccc}
\hline $\begin{array}{l}\text { Added } \mathrm{NaCl} \\
\text { concn }(\mathrm{mm})\end{array}$ & $\begin{array}{c}\mathrm{Na}^{+} \text {removal amount } \\
(\mathrm{mmol} / \text { plant })\end{array}$ & $\begin{array}{c}\mathrm{Na}^{+} \text {removal efficiency } \\
\left(\mathrm{mol} \cdot \mathrm{kg}^{-1} \text { dry weight }\right)\end{array}$ & $\begin{array}{c}\mathrm{Na}^{+} \text {uptake concn } \\
\left(\mathrm{mmol} \cdot \mathrm{L}^{-1} \mathrm{H}_{2} \mathrm{O}\right)\end{array}$ & $\begin{array}{c}\text { Water consumption } \\
(\mathrm{L} / \text { plant })\end{array}$ \\
\hline 6 & $0.13 \pm 0.00^{\mathrm{z}} \mathrm{b}^{\mathrm{y}}$ & $0.64 \pm 0.07 \mathrm{~b}$ & $0.42 \pm 0.01 \mathrm{~b}$ & $0.30 \pm 0.01 \mathrm{c}$ \\
8 & $0.17 \pm 0.00 \mathrm{~b}$ & $0.67 \pm 0.04 \mathrm{~b}$ & $0.56 \pm 0.01 \mathrm{~b}$ & $0.31 \pm 0.01 \mathrm{bc}$ \\
10 & $0.21 \pm 0.01 \mathrm{~b}$ & $0.79 \pm 0.07 \mathrm{~b}$ & $0.65 \pm 0.02 \mathrm{~b}$ & $0.33 \pm 0.01 \mathrm{~b}$ \\
200 & $6.95 \pm 0.29 \mathrm{a}$ & $10.02 \pm 0.70 \mathrm{a}$ & $18.63 \pm 0.63 \mathrm{a}$ & $0.37 \pm 0.01 \mathrm{a}$ \\
\hline
\end{tabular}

${ }^{\mathrm{z}}$ Data are means \pm SE $(\mathrm{n}=4)$.

${ }^{y}$ Different letters within a column denote significant differences $(P \leq 0.05)$ according to Duncan's new multiple range test.

Table 4. Correlation analysis among the parameters of $\mathrm{Na}^{+}$uptake and biomass accumulation $28 \mathrm{~d}$ after the start of treatment for Salicornia bigelovii grown in hydroponic solutions with different $\mathrm{NaCl}$ concentrations.

\begin{tabular}{|c|c|c|c|c|}
\hline Parameters & $\begin{array}{l}\text { Fresh wt } \\
\text { (g/plant) }\end{array}$ & $\begin{array}{l}\text { Dry wt } \\
\text { (g/plant) }\end{array}$ & $\begin{array}{l}\text { Marketable yield } \\
\quad\left(\mathrm{kg} \cdot \mathrm{m}^{-2}\right)\end{array}$ & $\begin{array}{c}\text { Water consumption } \\
\text { (L/plant) }\end{array}$ \\
\hline $\begin{array}{l}\mathrm{Na}^{+} \text {removal amount } \\
(\mathrm{mmol} / \text { plant })\end{array}$ & $0.99^{2 * *}$ & $0.99 * *$ & $0.99 * *$ & $0.92 *$ \\
\hline $\begin{array}{l}\mathrm{Na}^{+} \text {removal efficiency } \\
\quad\left(\mathrm{mol} \cdot \mathrm{kg}^{-1} \text { dry weight }\right)\end{array}$ & $0.99 * *$ & $0.99 * *$ & $0.99 * *$ & $0.92 *$ \\
\hline $\begin{array}{l}\mathrm{Na}^{+} \text {uptake concentration } \\
\left(\mathrm{mmol} \cdot \mathrm{L}^{-1} \mathrm{H}_{2} \mathrm{O}\right)\end{array}$ & $0.99 * *$ & $0.99 * *$ & $0.99 * *$ & $0.92 *$ \\
\hline Water consumption (L/plant) & $0.96^{* *}$ & $0.95^{*}$ & $0.96^{*}$ & \\
\hline
\end{tabular}

${ }^{\mathrm{z}}$ Data are expressed as correlation coefficient $(r)$ values.

* or ** next to the data indicates that correlations are significant at $P \leq 0.05$ or 0.01 , respectively.

The smaller cells may be a consequence of reduced turgor pressure resulting from a low vacuolar content of $\mathrm{Na}^{+}$and $\mathrm{Cl}^{-}$, because $\mathrm{Na}^{+}$ and $\mathrm{Cl}^{-}$may be preferentially accumulated in cell walls when availability of $\mathrm{NaCl}$ is limited (Rozema and Schat, 2013). In another species of the same genus, Salicornia dolichostachya, Katschnig et al. (2013) found that the growth rate of plants was $123 \%$ greater at 300 vs. $50 \mathrm{~mm} \mathrm{NaCl}$, but provided no explanation for this observation. It appeared that these Salicornia species might be considered "obligate halophytes," because they do not just tolerate high salinity levels, but also require considerable salinity levels to attain optimal growth (Rozema and Schat, 2013).

Contrary to our results, Brown et al. (1999) did not find that S. bigelovii grown in sand within draining containers reduced its growth rate in $\approx 9 \mathrm{vs}$. $\approx 180 \mathrm{~mm} \mathrm{NaCl}$. It has also been reported in some field studies that this plant species has shown minimal growth response across a broad salinity gradient (Dagar, 2005; Jaradat and Shahid, 2012). It is possible that the salt-stimulated (or suboptimal salinity-reduced) growth could only be observed in hydroponic systems with precise and constant salinity levels in nutrient solutions, but not in well-drained sand-culture systems nor in field studies (Rozema and Schat, 2013).

For leafy vegetables, yield potential greatly depends on biomass accumulation (Pan, 2008). In the present study, hydroponic $S$. bigelovii showed a significantly lower biomass accumulation, resulting in a substantially lower marketable yield at 6 to $10 \mathrm{vs}$. $200 \mathrm{~mm} \mathrm{NaCl}$, which is not consistent with the research result under sand culture reported by Brown et al. (1999), possibly as a result of the difference in culture systems (Rozema and Schat, 2013). However, the similar reduction of plant growth at 6 to 10 vs. $200 \mathrm{~mm} \mathrm{NaCl}$ in our experiment is tenable, because biomass accumulation is tightly linked to other growth attributes (Pan, 2008).

Similar to our results, Ayala and O'Leary (1995) found that the DW increase rate and the final fresh and dry mass of $S$. bigelovii plants grown in $5 \mathrm{~mm} \mathrm{NaCl}$ were significantly lower than those grown in $200 \mathrm{~mm} \mathrm{NaCl}$. They also demonstrated that the reduced biomass accumulation in 5 vs. $200 \mathrm{~mm}$ $\mathrm{NaCl}$-grown plants was not the result of an insufficient supply of photosynthates to support growth. Nevertheless, the reduced succulence (i.e., amount of water per unit dry mass), also supported by our study (Table 2), could be a major contributor to decreased fresh biomass when this halophyte is grown at a moderate salinity (Flowers and Colmer, 2008). Succulence might not only be a mechanism to dilute excess $\mathrm{NaCl}$ in leaf tissues (Glenn et al., 1999), but could also be a prerequisite for salt-stimulated growth of plants grown in a hydroponic system (Rozema and Schat, 2013).

Also, significantly lower water use efficiencies (fresh biomass accumulation based on water consumption) was observed for S. bigelovii in the 6 to 10 vs. $200 \mathrm{~mm} \mathrm{NaCl}$ treatments in our study. Previous studies have reported that halophytes could increase their water use efficiency in response to increased salinity, thereby minimizing the amount of water that must be transpired for each unit of growth (Ayala and O'Leary, 1995; Glenn et al., 1997, 1999). This finding implies that producing S. bigelovii in 6 to $10 \mathrm{vs.} 200 \mathrm{~mm}$ $\mathrm{NaCl}$ would require increased water consumption for similar yields and non-enhanced water conservation in crop production.

Decreased $\mathrm{Na}^{+}$uptake in hydroponic $\mathrm{S}$. bigelovii at moderate $\mathrm{NaCl}$ salinity possibly contributes to reduced biomass accumulation. The ability to accumulate $\mathrm{NaCl}$ for osmotic adjustment is a nearly universal trait of salt-tolerant plants (Glenn et al., 1999). For example, Salicornia spp. under hypersaline conditions can accumulate salt up to $37 \%$ to $52 \%$ of dry mass in its shoot tissues (Grattan et al., 2008; Ushakova et al., 2005). However, $\mathrm{Na}^{+}$uptake from the medium by plants was positively related to the $\mathrm{NaCl}$ concentration of root-zone solution, which might also affect the relative availability of $\mathrm{Na}^{+}$to the plant root system (Teixeira and Carvalho, 2008). Consequently, in the present study, when the external $\mathrm{NaCl}$ concentration decreased from 200 to 6 to $10 \mathrm{~mm}$, $S$. bigelovii significantly reduced $\mathrm{Na}^{+}$absorption (Table 3).

Also, a positive correlation was observed among $\mathrm{Na}^{+}$uptake, water consumption, and biomass accumulation (Table 4), suggesting the decreased $\mathrm{Na}^{+}$uptake in $S$. bigelovii at moderate $\mathrm{NaCl}$ salinity is possibly associated with reduced water consumption and biomass accumulation. Halophytes use the controlled uptake of $\mathrm{Na}^{+}$, balanced by $\mathrm{Cl}^{-}$and other anions, into cell vacuoles to drive water uptake into the plant against a low external water potential (Glenn et al., 1999). Consequently, when the external $\mathrm{NaCl}$ concentrations decreased from 200 to 6 to $10 \mathrm{~mm}$, $S$. bigelovii not only decreased $\mathrm{Na}^{+}$absorption, but also reduced water consumption (Table 3). Decreased water uptake by plants can directly result in reduced succulence and eventually in decreased biomass accumulation, because, as mentioned before, succulence can contribute greatly to biomass accumulation in halophytes (Flowers and Colmer, 2008; Rozema and Schat, 2013). Also, a previous study indicated that reductions in plant $\mathrm{Na}^{+}$absorption were greater in hydroponic systems than in soil with a similar decrease of external $\mathrm{NaCl}$ concentration 
(Tavakkoli et al., 2010). This difference may partly explain the suboptimal salinity-reduced growth that could only be observed in hydroponic systems but not in field soil studies.

In summary, our results suggest that at moderate $\mathrm{NaCl}$ salinity $S$. bigelovii is not a good candidate for hydroponic production as a vegetable as a result of decreased plant growth. Perhaps, the solutions with moderate $\mathrm{NaCl}$ concentrations (6 to $10 \mathrm{~mm}$ ) could be used first for hydroponic production of moderate salt-tolerant plant species such as purslane and then for high salt-tolerant plant species such as $S$. bigelovii when the $\mathrm{Na}^{+}$ concentration accumulates to $\approx 200 \mathrm{~mm}$.

\section{Literature Cited}

Adler, P.R., S.T. Summerfelt, D.M. Glenn, and F. Takeda. 2003. Mechanistic approach to phytoremediation of water. Ecol. Eng. 20:251-264.

Ayala, F. and J.W. O'Leary. 1995. Growth and physiology of Salicornia bigelovii Torr. at suboptimal salinity. Intl. J. Plant Sci. 156:197-205.

Brown, J.J., E.P. Glenn, K.M. Fitzsimmons, and S.E. Smith. 1999. Halophytes for the treatment of saline aquaculture effluent. Aquaculture $175: 255-268$.

Dagar, J.C. 2005. Ecology, management and utilization of halophytes. Bull. Natl. Inst. Ecol. 15:81-97.

Flowers, T.J. and T.D. Colmer. 2008. Salinity tolerance in halophytes. New Phytol. 179:945963.

Glenn, E., S. Miyamoto, D. Moore, J.J. Brown, T.L. Thompson, and P. Brown. 1997. Water requirements for cultivating Salicornia bigelovii Torr. with seawater on sand in a coastal desert environment. J. Arid Environ. 36:711730.

Glenn, E.P., J.J. Brown, and E. Blumwald. 1999. Salt tolerance and crop potential of halophytes. Crit. Rev. Plant Sci. 18:227-255.

Grattan, S.R., S.E. Benes, D.W. Peters, and F. Diaz 2008. Feasibility of irrigating pickleweed
(Salicornia bigelovii. Torr) with hyper-saline drainage water. J. Environ. Qual. 37:S-149-S156.

Grieve, C.M. and D.L. Suarez. 1997. Purslane (Portulaca oleracea L.): A halophytic crop for drainage water reuse systems. Plant Soil 192:277-283.

Jaradat, A.A. and M. Shahid. 2012. The dwarf saltwort (Salicornia bigelovii Torr.): Evaluation of breeding populations. ISRN Agronomy. 2012:1-10.

Kaşkar, Ç., J.A. Fernández, J. Ochoa, D. Niñirola, E. Conesa, and Y. Tüzel. 2008. Agronomic behaviour and oxalate and nitrate content of different purslane cultivars (Portulaca oleracea) grown in a hydroponic floating system. Acta Hort. 807:521-526.

Katschnig, D., R. Broekman, and J. Rozema. 2013. Salt tolerance in the halophyte Salicornia dolichostachya Moss: Growth, morphology and physiology. Environ. Exp. Bot. 92:32-42.

Kong, Y. and Y. Zheng. 2014. Hydroponic production of purslane as a sodium-removing vegetable in $\mathrm{NaCl}-$ rich nutrient solution. HortScience 49:201-206.

Kronzucker, H.J. and D.T. Britto. 2011. Sodium transport in plants: A critical review. New Phytol. 189:54-81.

Pan, R. 2008. Plant physiology. Higher Education Press, Beijing, China.

Pardossi, A., G. Bagnoli, F. Malorgio, C.A. Campiotti, and F. Tognoni. 1999. $\mathrm{NaCl}$ effects on celery (Apium graveolens L.) grown in NFT. Sci. Hort. 81:229-242.

Parks, G.E., M.A. Dietrich, and K.S. Schumaker. 2002. Increased vacuolar $\mathrm{Na}^{+} / \mathrm{H}^{+}$exchange activity in Salicornia bigelovii Torr. in response to $\mathrm{NaCl}$. J. Expt. Bot. 53:1055-1065.

Rozema, J. and H. Schat. 2013. Salt tolerance of halophytes, research questions reviewed in the perspective of saline agriculture. Environ. Exp. Bot. 92:83-95.

Savvas, D., V.A. Pappa, G. Gizas, and L. Maglaras 2005. Influence of $\mathrm{NaCl}$ concentration in the irrigation water on salt accumulation in the root zone and yield in a cucumber crop grown in a closed hydroponic system. Acta Hort. 697:93-98

Shannon, M.C. and C.M. Grieve. 2000. Options for using low-quality water for vegetable crops. HortScience 35:1058-1062.

Tavakkoli, E., P. Rengasamy, and G.K. McDonald. 2010. The response of barley to salinity stress differs between hydroponic and soil systems. Funct. Plant Biol. 37:621-633.

Teixeira, M. and I.S. Carvalho. 2008. Effects of salt stress on purslane (Portulaca oleracea) nutrition. Ann. Appl. Biol. 154:77-86.

Ushakova, S.A., N.P. Kovaleva, I.V. Gribovskaya, V.A. Dolgushev, and N.A. Tikhomirova. 2005 Effect of $\mathrm{NaCl}$ concentration on productivity and mineral composition of Salicornia europaea as a potential crop for utilization $\mathrm{NaCl}$ in LSS. Adv. Space Res. 36:1349-1353.

Van Os, E.A. 1998. Closed soilless growing systems in the Netherlands: The finishing touch. Acta Hort. 458:279-292.

Varlagas, H., D. Savvas, G. Mouzakis, C. Liotsos, I. Karapanos, and N. Sigrimis. 2010. Modelling uptake of $\mathrm{Na}^{+}$and $\mathrm{Cl}^{-}$by tomato in closedcycle cultivation systems as influenced by irrigation water salinity. Agr. Water Mgt. 97:1242-1250.

Ventura, Y. and M. Sagi. 2013. Halophyte crop cultivation: The case for Salicornia and Sarcocornia. Environ. Expt. Bot. 94:144-153.

Ventura, Y., W.A. Wuddineh, M. Myrzabayeva, Z. Alikulov, I. Khozin-Goldberg, M. Shpigel, T.M. Samocha, and M. Sagi. 2011. Effect of seawater concentration on the productivity and nutritional value of annual Salicornia and perennial Sarcocornia halophytes as leafy vegetable crops. Sci. Hort. 128:189196.

Webb, K.L. 1966. $\mathrm{NaCl}$ effects on growth and transpiration in Salicornia bigelovii a saltmarsh halophyte. Plant Soil 24:261-268.

Zerai, D.B., E.P. Glenn, R. Chatervedi, Z. Lu, A.N Mamood, S.G. Nelson, and D.T. Ray. 2010. Potential for the improvement of Salicornia bigelovii through selective breeding. Ecol. Eng. 36:730-739. 